European Journal of Pragmatism and American Philosophy

VIII-1 | 2016

Dewey's Democracy and Education as a Source of and a Resource for European Educational Theory and Practice

\title{
Moral Particularism and the Role of Imaginary
}

\section{Cases}

A Pragmatist Approach

Nate Jackson

\section{OpenEdition}

\section{Journals}

Electronic version

URL: http://journals.openedition.org/ejpap/468

DOI: $10.4000 /$ ejpap.468

ISSN: 2036-4091

\section{Publisher}

Associazione Pragma

Electronic reference

Nate Jackson, « Moral Particularism and the Role of Imaginary Cases », European Journal of

Pragmatism and American Philosophy [Online], VIII-1 | 2016, Online since 20 July 2016, connection on 01 May 2019. URL : http://journals.openedition.org/ejpap/468 ; DOI : 10.4000/ejpap.468

This text was automatically generated on 1 May 2019.

\section{(c) (i) (9)}

Author retains copyright and grants the European Journal of Pragmatism and American Philosophy right of first publication with the work simultaneously licensed under a Creative Commons AttributionNonCommercial-NoDerivatives 4.0 International License. 


\title{
Moral Particularism and the Role of Imaginary Cases
}

A Pragmatist Approach

\author{
Nate Jackson
}

1 Moral particularism is the view that there are no, or at most few, true universal moral principles and that competent reasoning and judgment do not require them. Instead of conformity to a principle, particularists affirm that actions are justified by a situation's salient features, and deny that a feature must have the same moral import in every situation in which it appears. But, since the reason-giving force of a feature in one situation is not a guarantor of its status elsewhere, particularism seems unable to account for moral learning from cases. In ethics, an imaginary case is a proxy for an actual situation, a description of a hypothetical state of affairs, and consideration of what would be morally required in the case is generally intended to provide action-guidance in a real situation. ${ }^{1}$ However, the features of a past or imaginary case are not precisely those of the real situation before us. It is possible that a feature might be salient in one case but not in another, and, on a particularist framework, appealing to cases seems likely to lead us astray.

2 Jonathan Dancy, particularism's primary advocate, acknowledges that particularism must accommodate a role for inferring from cases in moral reasoning. Dancy argues that cases, imagined and experienced, yield reminders; they provide a "checklist" of features that might have moral import. Here, I provide reason to think that this role for cases is unsatisfactory by looking at the impact that reviewing cases has in facilitating new moral appreciations. In response, I argue that John Dewey's work on the imagination along with contemporary elucidations of moral imagination in the pragmatist tradition allow for a more robust account of the ability to learn from cases consistent with particularism. Thus, while there are key distinctions between Dewey's ethics and contemporary particularism, Dewey's work on imagination affords an alternative particularist explanation of learning from imaginary cases. ${ }^{2}$ 


\section{Particularism, Holism and Narrative Rationality}

3 Particularism's fundamental position concerning moral reasons sets the parameters for its approach to cases. Foundational to the dispute between generalism, or principlebound accounts of morality, and particularism is a dispute concerning the behavior of moral reasons. Here, a reason is a consideration that favors, or makes a case for, an action. For particularists like Dancy, ordinary features of situations (that someone lied, that one borrowed property, etc...) serve as reasons. Underlying particularism is holism, the thesis that, "a feature that is a reason in one case may be no reason at all, or an opposite reason, in another" (Dancy 2004: 73). In Moral Reasons (1993), Dancy argues that,

The leading thought behind particularism is the thought that the behavior of a reason (or of a consideration that serves as a reason) in a new case cannot be predicted from its behavior elsewhere. The way in which the consideration functions here either will or at least may be affected by other considerations here present, [...]

4 and identifies this view as a "holistic view of the behavior of reasons" (Ibid.: 60). He contrasts this position with atomism, the thesis that "a feature that is a reason in one case must remain a reason, and retain the same polarity, in any other" (Dancy 2004: 70). If moral principles are in sufficient supply to ground moral reasoning, we should expect to find many atomistic (invariant) reasons, since principles specify features as having invariant moral importance. If most of the features that count for or against an action behave holistically, depending on other features in a situation in order to stand as a reason, we should not expect many moral principles.

Dancy offers several illustrative arguments for holism. First, particularists can envision a large number of cases in which the same feature can serve as a reason for an action, a case against an action, or have no bearing on whether an act is right or wrong. In effect, particularism denies the soundness of "switching arguments," arguments that isolate a feature and infer that because that feature is sometimes morally significant, it must matter in the same way in any case in which it appears. For example, we might maintain that an action's causing pain counts against it morally and envision a case in which causing pain is a morally significant feature (torturing innocents, for example). But Dancy invites us to consider his extracting a sea urchin's pin from his daughter's heel. A painless method of doing so, if available, would have been preferable, but no such method was available. Here, pain does not count against the action's moral propriety (Dancy 1993: 65). Similarly, Dancy asks us to imagine borrowing a book. Normally, that we borrowed something is reason to return it. But, if we learn the book is stolen, that we borrowed it no longer serves as a moral reason (Ibid:: 60). The same feature can thus be a reason or not, depending upon background features of the specific case. Particularists are confident that the supply of these cases is large enough that, for any given feature, there are cases in which it matters and cases in which it does not. ${ }^{3}$ This supply illustrates the contextdependence of moral reasons.

6 Another argument for holism is that other sorts of reasons are evidently holistic, and there is no need to posit a gulf between moral reasons and other sorts of reasons. For example, in the realm of practical reasons, "that there will be nobody much else around is sometimes a good reason for going there, and sometimes a very good reason for staying away." (Dancy 2004: 74). Or, take an epistemic example. Normally, being appeared to 
redly is a reason to accept that something is red. But, if I am aware that I am an inverted spectrum case, then something appearing red is a good reason to believe that it is blue. These cases, and cases like them, are motivation to abandon atomism in the practical and epistemic domains. Other examples of reason-behavior in non-moral spheres are similarly intuitive, and motivate Dancy's question, "[C]ould it be the case that moral reasons are quite different from all the others in this respect, being the only atomistic ones?" (Ibid.: 76).

7 A particularist account of learning from cases must cohere with holism. Importantly, such an account must also comport with Dancy's commitments regarding the structure of moral justification. Given his commitment to holism, Dancy re-envisions moral competence. He argues in rejecting the generalist (principled) account of moral reasons, that, "Moral justification is therefore not subsumptive in nature, but narrative" (Dancy 1993: 113). Generalists distinguish between reason-giving practices, descriptions of a situation and what it calls for, and the structure of moral justification. According to Dancy's characterization of generalism, moral justification has to take the form of subsumption, where a principle or rule provides reason for action. But when we describe a situation, we do not offer a principle under which the action is subsumed. We try, rather, to get another to see a situation as we do, to notice what we notice. Practices of justification, therefore, are distinct from practices of description on a generalist picture.

8 Particularists reject this distinction between moral description and moral justification. Rather, "to justify one's choice is to give the reasons one sees for making it, and to give those reasons is just to lay out how one sees the situation, starting in the right place and going on to display the various salient features in the right way" (Ibid.: 113). The structure of justification mirrors the structure of description, and the distinction between justification and description collapses. As a consequence of this collapse, Dancy maintains that the structure of moral justification is narrative, not subsumptive. Descriptions, if we are proceeding aright, "track" the salient features of a situation.

What we describe, if we perceive accurately, are the various salient features of the situation. But, more than just having a list of all of the relevant features, "a full view of circumstances will not only see each feature for what it is but will also see how they are related to one another. Such a view will grasp the shape of the circumstances" (Ibid.: 112). This metaphor of "shape" is central to Dancy's account of justification and rationality. A good description follows the shape of the situation, which provides moral reasons for action.

10 Finally, since moral rationality is a matter of tracking a situation's shape and perceiving its proper description, Dancy maintains that, "Rationality [...] is more like the ability to listen to and appreciate a story" (Ibid.: 144). Morally competent individuals are able to have a narrative construal of a situation and perceive what action that narrative supports. ${ }^{4}$ Narrative construals that in fact justify an action display the strengths the form allows, namely coherence (Ibid.: 114).

11 Holism about reasons and narrative rationality undermine reliance on principles and complicate an account of learning from cases. The interplay of features identified by holism is complex and speaks against the possibility of principles insofar as we cannot be assured that a feature will serve as a reason from case to case. The same feature can display different roles in different situations' narrative shapes. That a feature plays a particular role in one situation's story is no guarantee that it must have that role in other narratives. This potential for interference from other features presents a problem 
regarding the possibility of learning from cases, since a feature revealed as important in a past or imaginary case may not have that importance in a future situation. A particularist account of learning from cases must cohere with the commitment to narrative justification and with holism.

\section{Revealing Reasons: Particularism's Reception Regarding Cases}

Particularism motivates a deep suspicion of considering cases, insofar as it exhorts moral sensitivity to the narrative organization of a present case's features. Dancy writes,

The primary focus of particularism is the particular case, not surprisingly. This means that one's main duty, in moral judgement, is to look really closely at the individual case before one. Our first question is not "Which other cases does this one best resemble?," but rather "What is the nature of the case before us?." (Dancy 1993: 63)

Recent work on the role of analogical reasoning and cases in ethics puts Dancy's particularism in service of liming the kinds of cases that can legitimately test moral intuitions. ${ }^{5}$ Jakob Elster, for instance, cites particularism to suggest that "outlandish cases," cases that are conceivable but impossible in our world, can only have a limited role in moral argument, since the imagined case will not share the same profile of morally relevant features as those actually confronting us (Elster 2011: 252-3). In response, Joseph Spino maintains that such impossibility is only a concern if it signals a morally relevant difference from the actual case (Spino 2012: 30). Though defending a limited role for cases, Spino cites Dancy in arguing that the fact that the imaginary case is easier to assess than a real case potentially indicates a significant moral difference between the scenarios. Particularist considerations about the malleability of moral reasons across situations motivate caution "[...] when results from imaginary cases are put forth as evidence for drastic changes in our lives" (Ibid.: 31). These appropriations of Dancy aid in providing a taxonomy of imaginary cases in terms of similarity to the actual case and reveal limits of inferring from cases, but they do not afford avenues by which particularists could accommodate a role for abbreviated narratives.

Others call Dancy's particularism into question on the grounds that it cannot accommodate a role for reasoning from cases. Marcello Guarini, for instance, argues that, "our ability to engage in analogical argumentation and evaluate it depends on the ability to make multidimensional similarity assessments, and such assessments are usefully understood in terms of contributory standards [principles]" (Guarini 2010: 395). That is, analogical reasoning demands the recognition of similarities between cases, and a compelling account of these similarities relies on sharing features that contribute to an act's overall rightness or wrongness. Benedict Smith similarly warns against accepting any "bald" particularism, in light of the potential for comparative analysis to facilitate moral understanding (Smith 2002: 247). Analogical reasoning between cases fosters a kind of sensitivity to morally relevant features. Considering relevant similarities and differences between circumstances calls our attention to those features explaining why a given comparison is weak or strong, which bolsters moral knowledge. Smith exhorts,

we need to supplement particularism so as to make it flexible enough to accommodate the procedures of analogical reasoning, and the ability to compare and learn from different moral cases, imaginary or otherwise. (Ibid.: 247) 

particular judgments; Dancy affirms, sensitivity for the future. (Dancy 1993: 63) making consistent with holism. with moral rightness or wrongness.

In these treatments of particularism, the necessity of comparison for moral reasoning seems to be in tension with particularism's call for attentiveness to the present situation.

In these works, either the legitimacy of considering cases calls particularism into question, or particularist commitments severely limit the kinds of cases to which we can appeal. And, neither of these sets of arguments present an account of educative functions of the imagination beyond the potential for revealing some morally relevant feature or principle. Dancy supplies a nuanced rejoinder that particularism can accommodate a role for cases consistent with holism. However, even this treatment is too conscripted, and I look to Dewey's work to bolster a particularist approach to learning from cases, an approach responsible to the centrality of imagination in experience.

\section{Dancy on a Particularist Function for Cases}

In articulating a particularist approach to cases, Dancy considers the following appeal:

There is at present a controversy about whether Britain ought to return the Elgin Marbles to Greece. An argument might run as follows. Suppose that an orphan's estate is under the control of a not particularly conscientious trustee, who for reasons of his own allows a collector to remove part of that estate for a (not really sufficient) payment which the trustee then absorbs for his own purposes. The orphan eventually comes into his estate and attempts to recover his property. Whatever be the legal situation, must we not admit that the collector has some moral obligation to return the property? [...] So the collector ought to return the property. And similarly Britain ought to return the Elgin Marbles. (Dancy 1985: 143)

Admitting that this is reasonable instance of moral deliberation, Dancy maintains that particularism needs to make sense of such arguments. If it cannot, that inability would constitute a serious deficiency. Clearly, having a body of relevant experiences matters to

of course, a comparison with other cases may help us to decide how things are here, just as a long experience of car engines may help us to diagnose the fault this time. But this decision or diagnosis is still essentially particular. It would be surprising if a long experience in garages were no help to a mechanic; it would be surprising if a long and varied moral experience did not serve to sharpen one's

In lieu of actual moral experience, imagined cases supplement these lessons. The problem is that prior and imagined cases often share very few of the features of the actual case requiring a decision. If what justifies a course of action is the particular shape of the situation produced by the interplay of its various features, what can we take away from that case to inform our future reasoning, considering the context-dependence of moral reasons? Particularism requires an account of how moral experience can inform decision-

Generalists, on the other hand, seem to have an easy answer. They reject reasons-holism, and thus can say that a case highlights a principle. There's some feature (or a collection thereof) that always counts for or against the rightness of an action, and imaginary case bring this feature to the foreground. Thus, cases reveal principles that connect a feature

Of course, this conception relies on rejecting holism. Granting that moral reasons behave holistically, this interpretation of the role of cases closes. Dancy asks what role 
generalism could afford imaginary cases, given holism. Generalists' failure here is twofold. First, if cases are supposed to be action-guiding, one must ask if the imaginary case is a reliable guide to the actual case. But an imaginary case is an abbreviated narrative with unspecified background features. The incompleteness of the imagined case means that we cannot be sure that whatever features do the justificatory work in it will function the same way in the actual case. They might be frustrated in the actual case by features un-specified in the imagination. Thus, one cannot infer that because a feature matters in an imaginary case it must matter in the same way in an actual situation. Second, even if we learned from the imaginary case that a collection of properties has moral relevance, we can be assured that it has relevance in the actual case only if we already know that the actual case has that same collection and no more morally relevant features. But, if we already knew that, then we would know the "moral make-up" of the actual case, defeating the purpose of turning to imagined cases (Dancy 1985: 149).

While Dancy suggests that generalists lack a satisfying reply, he recognizes the impetus for particularists to respond to these worries as well. That is, one cannot say "so much the worse for imaginary cases." He writes,

Our duty as philosophers of ethics is to make sense of the discoverable patterns of moral reasoning; if we cannot do this it is a fault on our side, a fault in the philosophy rather than in the reasoning. (Ibid.: 149-50)

But, the commitment to holism means that a feature identified as important in one case might not be salient, or it might be salient in a different way, in a second case. Various background features might prevent that feature from serving the same function case to case. In an abbreviated narrative, features serve a particular role in organization. Even if the same features are in the real case, the real case has other features that may affect the moral import of shared features.

In response, Dancy suggests that cases can reveal that a particular property or feature can matter morally. Here, Dancy presents particularism in conciliatory mood, acknowledging that cases produce principles, but principles understood differently from a generalist view:

The suggestion I want to make is that a moral principle amounts to a reminder of the sort of importance that a property can have in suitable circumstances. (Dancy 1985: 150)

The case reveals a collection of features that exhibit moral importance. One learns of a particular feature that it can serve a particular function in the larger narrative that justifies actions, not that it must serve that role. This view, he thinks, accounts for our use of imaginary cases,

we can hope that an imaginary case is an abbreviated sketch of a case where a property can be seen to be important [...] This is especially so in the case of some parables of the New Testament, or the morals attached to Aesop's fables. (Ibid.: 151)

Since, in an imaginary case, a particular feature is morally important, we can infer that it can be morally important elsewhere. And, since principles amount to reminders that a feature can be important, Dancy maintains that this understanding of imaginary cases makes sense of the thought that we glean principles from consideration of particular cases.

Dancy offers the image of a store of principles as a kind of "checklist" of oft-important features (Ibid:: 150). The morally experienced person, who has a variety of cases and principles understood as reminders at hand, 
is at an advantage when coming to a decision in a particular case. He wants to be sure that he does not miss the importance or relevance of any relevant property. A panoply of moral principles, understood in the way suggested, can function as a sort of checklist for this purpose. (Ibid.: 150) King David over his lechery. David had committed adultery with Bathsheba, Uriah's wife, and then sent Uriah to the front lines of an ongoing war, assured of Uriah's death. At this point, Nathan confronts David:

The Lord sent Nathan to David. He came to him, and said to him, "There were two men in a certain city, one rich and the other poor. The rich man had a very many flocks and herds; but the poor man had nothing but one little ewe lamb he had bought. He brought it up, and it grew up with him and his children; it used to eat of his meager fare, and drink from his cup, and lie in his bosom, and it was like a daughter to him.

Now there came a traveler to the rich man, and he was loath to take one of his own flock or herd to prepare for the wayfarer who had come to him, but he took the poor man's lamb, and prepared that for the guest who had come to him." (2 Samuel 12:1-6)

Famously, David becomes angry and demands that the rich man be punished. Nathan responds, "You are the man!" and David subsequently feels contrition. Using the language of narrative rationality, David comes to appreciate the narrative shape of his situation only by acquaintance with the shape of another situation.

One test for the adequacy of Dancy's approach to cases is to ask, what feature(s) did the imaginary case highlight? In this case, of what was David reminded? Many of the shared features are those that David had to appreciate already in order to undermine Bathsheba and Uriah's relationship. For instance, the difference in power and the vulnerability of Uriah were evident in David's initial appreciation of the situation; otherwise he would not have been able to perform the act. The features furnished by the case are already present in David's appreciation. Since the case spurs new moral appreciation of the action without revealing missing features in the actual situation, Dancy's approach to cases is inadequate. 

parables. For instance, Martha Nussbaum visits her own interaction with Charles Dickens' David Copperfield, particularly the James Steerforth character. Troubled by her daughter's attraction to Steerforth, she re-considers the novel. At first, she recalls Steerforth as morally bankrupt: "as I remembered it, it was Dickens' intention to make the reader judge Steerforth from the moral point of view" (Nussbaum 1990: 335). However, in the process of re-reading the novel she feels the "power" of Steerforth's presence, and, like the character David Copperfield, she comes to feel love for Steerforth. Nussbaum says of the experience of reading,

Steerforth's gesture stirs us, as it hauntingly does, not because we see beyond it into something else, but because it is made, for us, a sensuous reality, because, by the spell of erotic and incantatory language we are brought, ourselves, into the charmed world of love. (Ibid.: 350)

The reassessment of Steerforth, from a character unworthy of admiration to an object of love, stems from sustained engagement in the literary world constructed by Dickens. The narrative he offers invites readers to adopt a particular point of view - Nussbaum calls this love's point of view - which Nussbaum argues contrasts with the moral point of view.

By arguing that we are brought to a new point of view, Nussbaum denies that she missed any particular salient feature on her first reading. Instead, through the experience of rereading, she comes to appreciate a description of Steerforth through Copperfield's excited eyes. Given Nussbaum's description of coming to adopt a new point of view, there are two competing appraisals of Steerforth, two competing "shapes" of the situation. Literature often invites one to organize experience in accordance with a perspective shaped by the author, and Nussbaum, especially in more recent work, echoes Dewey's contention that this imaginative engagement with artworks and literature enables new appreciations. ${ }^{6}$ While one may, like Nussbaum in the case of David Copperfield, be able to list properties that make Steerforth objectionable, the novel as a whole presents a very different organization of the relevant features.

The checklist image is not adequate to the task of explaining Nussbaum's reassessment of Steerforth. This account exemplifies learning from a case, as does the 2 Samuel example, and starkly suggests that cases do not merely furnish reminders. After drawing on contemporary work on imaginary cases to identify a particularist myopia regarding their potential functions, I turn to Dewey's work on the imagination to articulate an alternative role for imaginary cases consistent with Dancy's particularism.

\section{Particularist Myopia and the Educative Functions of Cases}

Recent work on thought experiments and imaginary cases enables a functional distinction in their educative roles. Though perhaps not precisely mirrored in Dewey's corpus, this distinction calls attention to a need for particularism to accommodate an "exploratory" function of cases, distinct from calling attention to features' potential moral importance. Dewey's work on imagination yields a response that comports with holism.

Working on the relationship between thought experiments and moral theory in a Wittgensteinian tradition, Cora Diamond delineates two approaches to imaginary cases. 
The first approach treats cases as "well-posed problems," the second as "exploration problems." In a well-posed problem, the description given requires, on pain of irrationality, a determinate conclusion without questioning either the parameters of the case or the background an individual brings to the case. In treating a problem as wellposed, we seek to determine what "canons of reasonableness" dictate as the appropriate practical outcome (Diamond 2002: 236). Exploration problems, however,

may be set up in such a way that assumptions underlying the initial understanding of the problem need to be questioned if the problem is to be resolved. The function of the discussion of such a problem may be precisely to probe what we take to be known. (Ibid.: 241)

Such problems are supposed to reveal that the assumptions or background conceptions brought to a situation need to be changed, and to facilitate development of that background. Exploration problems resemble cases like that of Nussbaum's re-reading of Dickens. Her imaginative involvement in the world of David Copperfield undermines her previous view that Steerforth is not an admirable character, changing her initial assessment. In familiar language, the case is not used to show the possible relevance of a feature. Instead, the case can serve to undermine an accepted appreciation and to facilitate a new appraisal in virtue of reassessing background assumptions. ${ }^{7}$

Others working on thought-experiments and cases have highlighted similar functional distinctions. For instance, in offering a helpful taxonomy of fictive narrative philosophy, Michael Boylan distinguishes between open-ended and closed cases:

Cases are fictive presentations that are structured so that the reader is enjoined to come up with his own response at the end. Some cases are open-ended so that the author is really interested in stimulating autonomous thinking within broad boundaries that limit the reader's evaluation. Others are closed; structured for right answers. (Boylan 2013: 73; emphasis added)

Per Boylan, closed cases offer a "conscripted vision of the world," demanding a listener respond from a particular framework rather than question the background assumptions one brings to a case (Ibid.: 74). In Dancy's treatment of cases, the imaginary situation supports a distinct course of action in virtue of a certain collection of features, but holism undermines the inference that the real situation supports the same action. However, open-ended cases promise an avenue around this pitfall. The results of "autonomous thinking" engendered by considering a case can facilitate new appraisals or mold the frameworks we use to evaluate cases.

Imaginary cases thus admit multiple educative functions. Well-posed or closed problems assess what the commitments of particular framework dictate given a situation's features, while other cases spur revision of the background conceptions used to understand the situation. In the kind of moral reasoning under consideration, Dancy's treatment of arguing from cases resembles the treatment of cases as closed or well-posed problems.

On Dancy's analysis, the facts of the actual case are settled; our perplexity is a symptom of not being able to comprehend the appropriate description of various relevant features. To address this perplexity, one employs an imaginary or past case that resembles a present one, but with an easier-to-grasp practical conclusion. As in a closed case, canons of reasonableness drive one to a particular, definite conclusion in terms of appropriate responses. Generalists infer that since that response is appropriate in the imaginary case, it should be appropriate in the real one. But this treatment conflicts with holism. Thus, 
the use of such cases must be restricted for particularists, as one sees in limiting the role of cases to yield "reminders."

In essence, Dancy treats cases as collections of features bearing a narrative shape more or less similar to an actual case. The operative features and their particular relationships comprise this shape. Thus, Dancy thinks cases reveal a feature's potential function in a larger description. Think of a case as a "mine" for potentially relevant features; individuals with more experience have more knowledge of such features. The lesson of one situation is that its features can play the role they do, and that information might be helpful in a real case. This treatment of cases views them as "closed"; we are to look for what the morally competent individual would see, and infer from her vision of the situation that some overlooked features matter.

But this approach does not account for the phenomenon of learning from imaginary cases, as evidenced by the cases of 2 Samuel and Nussbaum's reconsideration of Steerforth. To bolster the approach to cases, I suggest that particularism requires an account of their exploratory function. Dewey's comments on the imagination, especially in the context of his comments on sympathy and his analysis of imagination in Art as Experience and A Common Faith, expand a particularist account of learning from cases.

\section{Dewey on Imagination}

47 Contemporary interpreters of Dewey's ethics appreciate the centrality of imagination in his work. In his discussion of Dewey on moral imagination, Thomas Alexander argues that the imagination "constitutes an extension of the environment to which we respond. By reading the possibilities of the present, the present situation is itself transformed and enlarged," which facilitates the discovery of new ideals enabling resolution of situations with conflicting values (Alexander 2013: 197). Steven Fesmire characterizes a Deweyan account of moral competence in terms of "moral artistry," "[highlighting] the role of an expansive imagination that enables sensitivity to social bearing and consequences, intervenes widely and deeply in experience, and brings diverse elements together in a unified experience" (Fesmire 2003: 110). Fesmire emphasizes that, for Dewey, "art is paradigmatic of all experience," and that the imagination enables us to perceive relationships between a situation's features and possibilities (Fesmire 2015: 204, 135). The primacy of aesthetic qualities of experience and deliberation in Dewey's work motivate looking to his analysis of the imagination in art to illuminate its function in moral contexts.

Dewey's work on moral imagination, per Fesmire, exemplifies two intertwining and simultaneously operative aspects: an account of moral imagination as "creatively tapping into a situation's possibilities," and "empathetic projection" as "the animating mold of moral judgment" (Ibid:: 65, 132-3). The first theme includes Dewey's treatment of dramatic rehearsal, a stage of deliberation wherein one imagines taking possible courses of action and what would follow upon those actions. ${ }^{8}$ On Dewey's account, deliberation occurs when habits of action are frustrated. When this happens, "We give way, in our mind , to some impulse; we try, in our mind, some plan. Following its career through various steps, we find ourselves in imagination in the presence of the consequences that would follow" (LW 7: 275). We carry out various courses of action through representation in imagination and see what experiences they produce. Particularists might understand this rehearsal as a method, an epistemic tool, for appreciating the salience of an action's 
relationship to future events and experiences. ${ }^{9}$ However, cases like those in 2 Samuel and in Nussbaum's work do not appear to produce new appraisals by the imaginative rehearsal of one's own possible actions. For Dewey, imagination facilitates our appreciation of salient features beyond rehearsing possible lines of action. There is a danger that focusing on dramatic rehearsal as an imaginative temporal extension of a course of action unhinged from sympathy will ignore the mystery that Dancy highlights.

Still, particularists can look to Dewey's work on the imagination to articulate a role for exploratory or open-ended cases. Recall that Fesmire identified two themes in Dewey's work on the imagination, "creatively tapping into a situation's possibilities," and "empathic projection." Interaction with art and imaginary cases requires this latter operation of imagination to be educative.

The theme of "empathetic projection" derives from Dewey's discussion of sympathy. Regarding empathetic projection, the empathetic individual is one who has the ability to "take on" another point of view, and to construe a situation from another's perspective. Dewey writes, "sympathy carries thought beyond the self [...] [it renders] vivid the interests of others" (Ibid.: 270). To be sympathetic is, "to put ourselves in the place of others, to see things from the standpoint of their purposes and values" (Ibid.: 270; emphasis added). This ability facilitates new descriptions as a different perspective provides different concerns, limitations, and aims. ${ }^{10}$ By taking on another point of view, we construe a situation differently, possibly unsettling our initial descriptions. This role of empathic projection suggests that the same collection of features is open to different narrative structures, and that these different shapes are accessible and can be subject to evaluation.

51 Moreover, Dewey sees this operation of the imagination in ordinary communication insofar as it has an aesthetic dimension: Dewey writes,

To be a recipient of communication is to have an enlarged and changed experience. One shares in what another has felt and in so far, meagerly or amply, has his own attitude modified [...] one has to assimilate, imaginatively, something of another's experience in order to tell him intelligently of one's own experience. All communication is like art. (MW 9: 8-9; emphasis added)

Empathetic projection is thus ingrained in Dewey's account of communication itself. Since communication is like art and is educative in virtue of this similarity, one should look to Dewey's account of art to articulate an account of moral learning from imagined experience. For Dewey, aesthetic imagination has a central role in genuine experience, including moral deliberation. As commentator Duane Cady writes, "For Dewey, the opposite of the aesthetic is the arbitrary and a routine submission to conventional practices and procedures" (Cady 2005: 51). Dewey sees the operation of imagination as a pre-requisite for understanding a situation at all; he contends in Democracy and Education that the imaginative is, "a warm and intimate taking in of the full scope of a situation," and develops his account of imagination in other works, especially A Common Faith and Art as Experience (MW 9: 244). Dewey's analysis in these works illustrates the workings of imagination in experience more broadly, and offer outlines of imagination in experience applicable to moral reasoning. ${ }^{11}$

In Art as Experience, Dewey maintains, "imagination is the chief instrument of the good," consisting in a "presentation of ideals" (LW 10: 350). In A Common Faith and Art as Experience, Dewey articulates an educative function for poetry, literature and art. The 
"moral function" of such imaginative productions is captured by the unification of concrete facts and ideals. In A Common Faith, Dewey (LW 9: 49) writes,

The aims and ideals that move us are generated through imagination. But they are not made of imaginary stuff. They are made of the hard stuff of the world of physical and social experience [...] The new vision does not arise out of nothing, but emerges through seeing, in terms of possibilities, that is, of imagination, old things in new relations. embodiment is the best evidence that can be found of the true nature of the imagination" (LW 10: 279). Dewey continues to define imagination in terms of the interaction of two "modes of vision," one inner and one outer, such that, "an imaginative experience is what happens when varied materials of sense quality, emotion, and meaning come together in a union to mark a new birth in the world" (Ibid.: 272). Regarding the two kinds of vision, outer vision is the report of the sense modalities, a list of perceived facts, while inner vision "seems wraith-like," and is formed by "ideals" (Ibid.: 273). Imaginative interaction of the two modes of vision culminates in a narrative-structured experience. 

and the material available to express it interact. Outer vision includes the materials presented by a situation, its features. Inner vision includes the appreciation of ideals as mentioned in A Common Faith. In that work, imagination is the vehicle by which ideals form out of experienced material, yielding a vision of possibilities to direct action. The same experienced features can exemplify different narratives, depending upon the organization provided by these ideals. Inner vision provides organization to a collection of features provided by outer vision.

Key to the educative function of art, for Dewey, is that imaginative productions form a challenge to those who interact with them. We see new narrative and organizational structures when interacting with artwork, and this interaction illuminates a particularist understanding of learning from cases. In the work of art,

meanings imaginatively summoned, assembled, and integrated are embodied in the material existence that here and now interacts with the self [...] [The artwork is] $a$ challenge to the performance of a like act of evocation and organization, through imagination on the part of one who experiences it. (Ibid.: 278; emphasis added)

61 These comments on the educative function of artworks clarify the role Dewey sees for cases like 2 Samuel or Nussbaum's experience (1990). In an artwork, as in a case, various features are unified by an organization, in Dancy's terms, a narrative "shape." Observers interact with this organized unity, not just a list of individual elements. This interaction consists in an activity of organizing experienced elements, as one does in empathetic projection, or, Dewey thinks, in ordinary communication. This action then effects new organizations of other situations. Dewey elaborates,

While the perception of the union of the possible with the actual in a work of art is a great good, the good does not terminate with the immediate and particular occasion in which it is had. The union that is presented in perception persists in the remaking of impulsion and thought. (LW 10: 351; emphasis added) cy's vocabulary is useful, since the notions of "ideal" and "inner vision" might invite confusion. In a work of art, a collection of features is given organization or shape by an author or artist. By interacting with this shape, Dewey thinks, one is "challenged" to produce a like act of organization out of materials (features) in a concrete situation. Instead of revealing features, the case-as-artwork becomes provocation to mold the actual set of features in accordance with a case's organization. In addition to cases showing that a particular feature can matter, they also demonstrate the coherence of a narrative form that organizes those features.

64 Consider the 2 Samuel example again. Dewey might explain David's learning as follows: when Nathan presents the tale, he presents an abbreviated narrative that David encounters as an actual situation with a particular narrative organization. David is the king, and interacts with the tale as one who must exercise some authority in the case. The practical organization of the case yields a conclusion that the rich man was unjust. The subsequent "you are the man" elicits a "like act of organization." The narrative presented with the elements of the rich man and the poor man "fits" David's case. The act of 
organization provoked by Nathan's story yields a description of the case with the strengths of narrative.

On this analysis, an artwork's function can be exploratory; it challenges an initial construal of a situation by exploring what we take to be known. The case does not yield new features nor does it demonstrate that other features can function differently. It does not demonstrate what canons of reasonableness dictate given a collection of features. Instead, it alters "inner vision" or those background conceptions individuals bring to a situation that give it shape. Cases-as-artworks mold "inner vision" through imaginative participation, and individuals bring the background formed by interaction to other situations; they are challenged to a like act of organization. Dewey's account of the educative function of the imagination in art allows an expansion of the role of cases and the conclusions they warrant.

\section{Developments of Dewey: Mark Johnson, Metaphor and Moral Argument}

The treatment of artwork as educative suggests that, taken as artworks, imaginary cases provoke new organizations of familiar materials. Mark Johnson's work drawing on Dewey's analysis and recent developments in cognitive science clarifies how a case can serve this end. An ethics responsible to human nature, Johnson argues, embraces a central role for imagination and supports "conscientiousness" as a moral ideal, a quality resisting principle-bound ethics and exhibiting "the mental and emotional flexibility to imagine new solutions and new ways of going forward that resolve pressing moral problems" (Johnson 2014: 216). Johnson draws on recent research in cognitive sciences to critique rule-bound accounts of morality, suggesting instead: "moral deliberation is an activity of transformative thinking that reconfigures the situation by ordering the materials of that situation into a new gestalt" (Ibid.: 118). In an earlier work, Johnson develops an account of the necessity of "imaginative framing devices" like metaphor for moral understanding, and maintains that imagination provides narrative elements that structure experience (Johnson 1994: 170). Johnson's work on metaphor illustrates how interaction with artwork and cases is potentially educative and exploratory, and enables an articulation of the use of imaginary cases consistent with Dancy's particularism.

Research in cognitive sciences shows "how abstract thinking traffics mostly in metaphor, and how our reasoning is grounded in our bodily (sensory-motor) experience" (Johnson 2014: 196). Johnson argues, in accord with Dewey, that synthesizing or making sense of experience is an imaginative activity and "that narrative structure provides the most comprehensive synthetic unity that we can achieve" (Johnson 1994: 170). Moreover, Johnson echoes Dancy's claim that justification and description coincide when he argues,

The way we frame a given situation will determine what we ought to do about it, and our semantic frames typically involve metaphorical concepts. Consequently,

our reasoning about these situations will typically be based on metaphors. (Ibid.: 52)

Here, metaphor refers to structures, relations and vocabulary from one domain mapping onto another.

In a central example, Johnson examines an individual's moral understanding of marriage under different metaphors. While details of the case are unimportant, what is important is that marriage can be described using different narrative structures; it can be understood as a journey, a commodity exchange, an organic unity, etc. 
Each device is projected from a different domain onto the description of marriage. What an individual discovers is that these metaphorical frames allow better and worse descriptions of marriage and its difficulties; Johnson writes of someone exploring these different descriptions that,

He is trying out each possible explanation to see how it "feels," how it makes sense of his experience. And as he performs this test he is glimpsing possible structurings of his marriage. (Johnson 1994: 61) faced death. Death is not an "enemy" in their stories; rather, it is an especially unsettling moment because it marks an uncertainty in a journey. By making use of some examples (e.g., Hamlet's soliloquy, Socrates' final moments), they give new narrative organization to the grandfather's case. In particular, they provide a story engaging the grandchild. Through this exploration and imaginative participation in the parents' stories, the child participates in a different method of organizing the situation. The narratives offered by the parents employ a different metaphor, imbuing the situation with a different shape.

Crucially, the child is not to infer that because the journey metaphor affords a particular moral appraisal in an imaginary case that it must do so here. Through further inquiry, the grandchild can test the competing construals afforded by different metaphors and see which is stronger. Dewey (LW 10: 273) writes, 
The peculiar quality of the imaginative is best understood when placed in opposition to the narrowing effect of habituation [...] The imaginative endures because, while at first strange with respect to us, it is enduringly familiar with respect to the nature of things. structure and facilitate descriptions. An imaginary or past case might reveal that a feature is important, or it might reveal that a given vocabulary or metaphor can yield a coherent description. In the 2 Samuel case, David learns that his own activity can be understood using the vocabulary of theft and the characters of the rich man and the poor man. The imaginary case provided narrative elements that imbue the situation with a new shape, undermining the initial appraisal. An application of metaphor can yield a coherent narrative, changing the background conceptions that we initially used to organize a situation.

\section{Art, Moral Reasoning, and Consistency with Particularism}

Recall that Dancy's focus pertains to the role cases can have as instances of moral reasoning. Dancy identifies the appeal to cases as a form moral argument, and the challenge is to make sense of that form of inference from a particularist point of view. I have argued that Dewey's work on imagination allows an understanding of cases as revealing different narrative "shapes" that might apply to a concrete situation. Here, I briefly explicate how cases understood as artworks inform moral reasoning in a manner consistent with Dancy's particularism. Dewey's analysis coheres with the commitment to narrative justification, does not rely on "importing" features into concrete situations, and does not deny holism, the fundamental position underlying particularism.

In rejecting principle-bound accounts of justification, Dancy affirmed that justification has a narrative structure. The narratives are comprised of a situation's salient features. The appeal to cases as revealing narrative elements to be used in a concrete situation comports with Dancy's account of justification. The success of a description can be read as an endorsement of the helpfulness of its narrative elements in organizing a situation's features. And, as an argument for a certain narrative structure, the "conclusion" of a case need not be limited to the claim that some feature may contribute to the overall case for or against an action. Instead, cases can show that different vocabularies and metaphorical structures, elements of "inner vision," give rise to different descriptions or shapes of a situation.

In his own example of the orphan and malevolent trustee, Dancy does not tell the reader what feature turned out to be important; no analysis shows how that case drove an understanding of what Britain ought to do with the Elgin Marbles. The case did, however, reveal that in a metaphor of familial and legal relationships, the actions of the trustee were unjustified and vicious. That narrative displayed a unity, had the strengths afforded

European Journal of Pragmatism and American Philosophy, VIII-1 | 2016 
the form, and employed the vocabulary of family and legal relationships. The structures and characters employed in the imaginary case afford a narrative description of the actual case. That one could describe the situation without the analogy shows merely that other narrative descriptions of the case are available.

My suggestion is that Dewey's analysis of the imagination allows particularists to see the imagination as the "experimental ground" for narrative structures and devices that may or may not turn out to "fit" a situation at hand. There is no need here to deny the narrative structure of justification. Instead of revealing that a certain property or collection of properties can be salient, exploration contributes to our abilities to offer different descriptions of concrete situations. Examining cases can probe and develop background conceptions and dominant metaphors brought to a situation by an observer. Since the function of the imagination is to explore structures that afford new narrative descriptions of situations, the analysis here comports with Dancy's claim that justification is narrative in structure.

Crucially, consistency with particularism demands that appeal to the imaginary case does not "import" features to the real case that are not there. Some might think that Dewey's view of the imagination is incompatible with particularism on this point. He sometimes writes as if the imagination imbues a situation with properties that are not "in" the concrete situation:

the reality of ideal ends as ideals is vouched for by their undeniable power in action. An ideal is not an illusion because imagination is the organ through which it is apprehended. For all possibilities reach us through the imagination. In a definite sense, the only meaning that can be assigned the term "imagination" is that things unrealized in fact come home to us and have the power to stir us. (LW 9:43)

However, the "things unrealized in fact" need not be additional features of a situation; the imagination need not operate by imputing saliences to situations that they do not have. Recall, Dancy argues that situations exhibit a practical shape, a narrative structure. The imagination as the unification of ideal and real can be understood as the unification of different narrative structures with a particular set of features. Since the imagination can disclose different "shapes" for the same set of features, it can operate by revealing different narratives about the same situation. These different shapes can be subject to evaluation. Cases as arguments show that a different metaphorical structure can be fruitful.

Consider the Nathan-David exchange again. Perhaps David's position of power inured him to construing his own action as theft; instead he might have seen the situation as the just or normal actions of a monarch. Nathan's abbreviated story offers a competing narrative shape for the situation. Through participation in that act of organization, David returns to his own situation provoked to re-organize its actual features.

Similarly, Nussbaum's initial encounter with Steerforth left her disliking the character, worrying about her daughter's love for Steerforth since there must be nothing admirable about him. By imaginatively participating in the story, Nussbaum comes to appreciate a different shape. There are no new, previously unnoticed features in her second reading of the novel, but through the "incantatory language" of the novel, she re-organizes its elements. By participating in the novel's organization, she meets the challenge to a like act of organization, undermines her initial appraisal, and comes to a new appreciation of the situation without introducing or omitting elements. 

every situation, is the leading thought behind particularism, the analysis offered here must cohere with this commitment. Dewey's approach to imaginary cases does not require any feature or collection of features to have invariant moral import. As moral argument, the case does not show that because a collection of features in one instance justifies an action, that the same collection will matter elsewhere. Instead, since a particular narrative organization works in one case, one knows that those characters, vocabulary and general metaphoric structure can function to make sense of a collection of features. Because those narrative elements work in the imagined situation, they might yield an understanding of a second case. While it may be unintended, Dewey's account of artwork as "eliciting a like act of organization" can make sense of the use of cases in moral learning and reasoning on a particularist framework. Thus, Dancy's particularism, using Dewey's analysis, can provide a robust account of learning from cases, and is not limited to considering cases solely as sources of "reminders."

I would like to thank several readers, especially Stuart Rosenbaum and two anonymous referees, for their helpful comments on earlier drafts.

\section{BIBLIOGRAPHY}

ALBERTZART M., (2014), Moral Principles, New York, Bloomsbury Academic.

ALEXANDER T. M., (2013), “John Dewey and the Moral Imagination: Beyond Putnam and Rorty toward a Postmodern Ethics," The Human Eros: Eco-ontology and the Aesthetics of Existence, New York, Fordham University Press.

BAKHURST D., (2007), "Pragmatism and Ethical Particularism," New Pragmatists, edited by Cheryl Misak, New York, Oxford University Press.

BoYLAN M., (2013), "What Fictive Narrative Philosophy Can Tell Us: Stories, Cases, and Thought Experiments," Revista del Instituto de Filosofia, Universidad de Valparaiso, 1, 2, 61-81.

CADY D., (2005), Moral Vision: How Everyday Life Shapes Moral Thinking, New York, Rowman \& Littlefield Publishers.

CASPARY W., (2006), "Dewey and Sartre on Ethical Choice: Dramatic Rehearsal Versus Radical Choice," Transactions of the Charles S. Peirce Society, 42, 3, 367-93.

DANCY J., (1985), “The Role of Imaginary Cases in Ethics," Pacific Philosophical Quarterly, 66, 1\&2, 141-53.

DANCY J., (1993), Moral Reasons, Cambridge, MA, Blackwell Publishers.

DANCY J., (2004), Ethics Without Principles, New York, Oxford University Press.

DAVIS D., (2004), "Rules and Vision: Particularism in Contemporary Ethics," PhD Dissertation, Saint Louis University.

DAVIS M., (2012), “Imaginary Cases in Ethics," International Journal of Applied Philosophy, 26, 1, 1-17. 
DEWEY J., (2008), Art as Experience. The Later Works of John Dewey, 1925-1953, volume 10, edited by Jo Ann Boydston, Carbondale, IL, Southern Illinois University Press.

DEWEY J., (2008), A Common Faith. The Later Works of John Dewey, 1925-1953, volume 9, edited by Jo Ann Boydston, Carbondale, IL, Southern Illinois University Press.

DEWEY J., (2008), Democracy and Education. The Middle Works of John Dewey, 1889-1924, volume 9, edited by Jo Ann Boydston, Carbondale, IL, Southern Illinois University Press.

DEWEY J., (2008), Ethics. The Later Works of John Dewey, 1925-1953, volume 7, edited by Jo Ann Boydston, Carbondale, IL, Southern Illinois University Press.

DIAMOND C., (2002), “What If X Isn't the Number of Sheep? Wittgenstein and Thought-

Experiments in Ethics," Philosophical Papers, 31, 3, 227-50.

ELSTER J., (2011), “How Outlandish Can Imaginary Cases Be?," Journal of Applied Philosophy, 28, 3, 241-58.

FESMIRE S., (2003), John Dewey and Moral Imagination: Pragmatism in Ethics, Bloomington, IN, Indiana University Press.

FESMIRE S., (2015), John Dewey, New York, Routledge.

GENDLER T., (2000), Thought Experiment: On the Powers and Limits of Imaginary Cases, New York, Garland Publishing.

GUARINI M., (2010), "Particularism, Analogy, and Moral Cognition," Minds \& Machines 20, 385-422.

JACKSON N., (2016), "John Dewey and the Possibility of Particularist Moral Education," Southwest Philosophy Review, 32, 1, 215-24.

JoHNSON M., (1994), Moral Imagination: Implications of Cognitive Science for Ethics, Chicago, University of Chicago Press.

JOHNSON M., (2014), Morality for Humans: Ethical Understanding from the Perspective of Cognitive Science , Chicago, University of Chicago Press.

LEKAN T., (2003), Making Morality: Pragmatist Reconstruction in Ethical Theory, Nashville, TN, Vanderbilt University Press.

NussBaum M., (1990), “Steerforth's Arm: Love and the Moral Point of View," Love's Knowledge, New York, Oxford University Press.

nussbaum M., (2010), Not For Profit: Why Democracy Needs the Humanities, Princeton, NJ, Princeton University Press.

PAPPAS G., (2008), John Dewey's Ethics: Democracy as Experience, Bloomington, IN, Indiana University Press,.

SMITH B., (2002), "Analogy in Moral Deliberation: The Role of Imagination and Theory in Ethics," Journal of Medical Ethics 28, 244-8.

SPINO J., (2012), “Defusing the Dangers of Imaginary Cases," Journal of Applied Philosophy, 26, 1, 29-37.

The New Oxford Annotated Bible, New Revised Standard Version, (2001), New York, Oxford University Press.

WALSH A., (2011), “A Moderate Defense of the Use of Thought Experiments in Applied Ethics," Ethical Theory and Moral Practice 11, 467-81. 
WALSH A., (2013) “Thought Experiments in Ethics," in H. Lafollette, (ed.), The International

Encyclopedia of Ethics, Oxford, Wiley Blackwell.

\section{NOTES}

1. Walsh (2011: 469) offers a similar definition. See also his introduction in Walsh (2013: 5143). Gendler 2000 also offers extensive treatment of the role of imaginary cases in philosophical inquiry generally, not solely in moral argument.

2. Various commentators highlight central aspects of the distinctions between particularism and pragmatism. Some, like Todd Lekan and Gregory Pappas, offer arguments for the strength of Dewey's ethics over Dancy's particularism. In particular, these authors draw on Dewey's work to disclose a role for principles in moral deliberation. Others, like David Bakhurst, consider the possibility of a fruitful intersection between the views. See for instance: Bakhurst (2007: 122-41); Fesmire (2015: 143); Jackson (2016: 215-24); Lekan (2003: 96-102); and Pappas (2008: 51-5).

3. Albertzart helpfully argues that a certain criticism of thought-experiments in "contrast arguments" is at the heart of Dancy's particularism. He writes, "There is widespread reliance on the possibility of making progress by extracting what we take to be morally relevant in one particular situation and transplanting it into a new hypothetical situation, and vice versa. The assumption is that if something is morally relevant in one case it must remain relevant, and relevant in a similar way, in any other. This atomism is rarely openly admitted, and, if asked, most moral philosophers would probably deny it. However, many arguments nevertheless implicitly rely on atomism and - suitable rephrased - Dancy's theory helps to expose this assumption" (Albertzart 2014: 52).

4. Bakhurst (2007: 138-9) notes that "particularists frequently invoke aesthetic phenomena [like narrative] to illuminate their position," but "[...] it remains unclear how seriously we are to take this parallel." He suggests that Dewey's work on the imagination might be of aid here, but does not develop this suggestion, instead focusing attention on supposed inadequacies in Steven Fesmire's argument for artistry as a paradigmatic metaphor for morality.

5. Some of this work actually considers the limitations of inferring from imaginary cases in ethics on a generalist framework, and offers only a cursory treatment or mention of moral particularism. Walsh, for example, defends a limited role for cases, requiring a "contingency clause" that "respects the fundamental contingency of applied ethical problems" (Walsh 2011: 468). In the course of his argument he acknowledges that Dancy's particularism demands more than a suspicion of cases, writing, "For a particularist, like Jonathan Dancy (1993), moral judgments are particular to the cases in question and we cannot generalise from other cases" (Ibid $.: 479)$.

6. In a more recent work Nussbaum draws on Dewey and Rabindranath Tagore to argue that literature helps develop the imaginative capacity to "see the world from the viewpoint of other people" (Nussbaum 2010: 44, 102-11). Her comments echo Dewey's contention that, "They [arts and literature] reveal a depth and range of meaning in experiences which otherwise might be mediocre and trivial. They supply, that is, organs of vision" (MW 9: 247).

7. To illustrate, Diamond considers the ring of Gyges tale from Plato's Republic as both a wellposed and an exploration problem. Conceived as an exploration problem, the ring of Gyges functions as a sounding board for one's conception of the moral life itself, and various arguments in the Republic following book II undermine the sophist's response. The case cannot be appreciated without undermining pre-conceived notions of justice: "our canons of reasonableness are supposed to be taken by us to determine a unique solution. But the assumptions with which we understand the situation need to be changed" (Diamond 2002: 236). 
8. See the following for more extended treatments on deliberation and dramatic rehearsal: Caspary (2006: 367-93); Fesmire 2003, especially Chapter 5; and Pappas 2008, especially 98-108.

9. One lesson particularists might glean by focusing on dramatic rehearsal as a temporally complex imaginative "trial" of a course of action is that the function of moral imagination is necessary to appreciate the salience of a situation's relationship to past and future situations. One shortcoming of particularism, then, for which the pragmatist tradition offers resources, would be in understanding the practical necessity of the imagination for revealing moral features of situations that involve continuity with past and future situations. This analysis potentially alleviates worries that particularism renders the moral life too episodic. Davis (2004: 74-5) develops this point in Rules and Vision: Particularism in Contemporary Ethics, illustrating how Socrates' final moments in the Crito require Socrates to connect his present action to his past actions. And, plausibly, the temporal complexity of dramatic rehearsal can help Dancy's particularism regarding this charge, as it might reveal disunity between past and future experiences.

10. In addition to offering this account of a habit of sympathy, Dewey maintains that sympathy is necessary for moral judgment, claiming, "Sympathy is the animating mold of moral judgment [...] because it furnishes the most efficacious intellectual standpoint" (LW 7:270).

11. Dewey affirms that "all conscious experience has of necessity some degree of imaginative quality" (LW 10: 276).

\section{ABSTRACTS}

I argue that John Dewey's analysis of imagination enables an account of learning from imaginary cases consistent with Jonathan Dancy's moral particularism. Moreover, this account provides a more robust account of learning from cases than Dancy's own. Particularism is the position that there are no, or at most few, true moral principles, and that competent reasoning and judgment do not require them. On a particularist framework, one cannot infer from an imaginary case that because a feature has a particular moral importance there, that it must have that import in an actual case. Instead, for Dancy, cases can yield "reminders," and a person with a lot of experience (real or imagined) brings a "checklist" of features that can matter to a situation. Using the Nathan-David exchange from 2 Samuel and Martha Nussbaum's "Steerforth's Arm" from Love's Knowledge, I show that this account does not explain all instances of learning from cases. Drawing on recent work on cases, I argue that cases can be educative by serving an exploratory function, probing what one takes to be known and provoking change in the background one uses in evaluating a situation. I then argue that Dewey's work on imagination in his comments on sympathy and in A Common Faith and Art as Experience enables such a role for cases on a particularist framework. Mark Johnson's recent work on metaphor further illuminates how Dewey's account of art can be exploratory. I contend that this account affords an exploratory role for cases consistent with Dancy's particularism. 


\section{AUTHOR}

NATE JACKSON

Capital University

Njackson1331[at]capital.edu 